\title{
Akt inhibitors: mechanism of action and implications for anticancer therapeutics
}

\author{
Jaikrit Bhutani ${ }^{1}$, Asfandyar Sheikh $2,4^{*}$ and Asfandyar Khan Niazi ${ }^{3}$
}

\begin{abstract}
Akt, better known as protein kinase B (PKB), is a serine/threonine-specific protein kinase which acts as mediator via PI3K/Akt pathway in many biological processes like glucose metabolism, apoptosis, cell differentiation and transcription. Akt1 gene amplification has been implicated in gastric carcinoma while Akt2 amplification has been linked with ovarian, pancreas, breast and stomach tumors. The use of Akt inhibitors as monotherapy or in combination with other anticancer drugs could be useful for combating drug resistance and improving response. Thus, comprehensive understanding of Akt and its linked signaling pathways (PI3K, PKB, mTOR etc.) is necessary to lead to newer drug development and use.
\end{abstract}

\section{Letter to the editor}

Akt, better known as protein kinase B (PKB), is a serine/ threonine-specific protein kinase which acts as mediator in many biological processes like glucose metabolism, apoptosis, cell differentiation and transcription. Three members in the Akt family have been identified until now, namely Akt1, Akt2 and Akt3. While Akt2 is mostly involved in glucose transport and Akt3 is highly expressed in brain tissue, Akt1 plays a key role cellular survival and metabolism [1,2].

The Akt cascade is activated by a host of events, most commonly via binding of ligands such as growth factors, cytokines and hormones to various receptors, the most important of which are receptor tyrosine kinases (RTK) (Figure 1). Binding of ligands to RTK causes autophosphorylation of tyrosine residues on the intracellular domain of the receptor. This causes the recruitment of PI3K to the phosphotyrosine residues via SH2 domain adapters in the regulatory domain (p85) of PI3K. This causes conformational changes in the catalytic domain of PI3K, which in turn results in kinase activation. This is followed by the PI3K mediated phosphorylation of membrane bound PIP2 to generate PIP3. PIP3 then binds to the PH domain of Akt, thereby anchoring it to the plasma membrane and allowing its phosphorylation and activation by PDK1 [3].

\footnotetext{
* Correspondence: asfandyarsheikh@gmail.com

${ }^{2}$ Dow Medical College, Dow University of Health Sciences, Karachi, Pakistan

${ }^{4}$ Pakistan Research Evolution Scientific Society, Baba-e-Urdu Road, Karachi

74200, Pakistan

Full list of author information is available at the end of the article
}

The activity of Akt is negatively regulated by PTEN, SHIP and CTMP [4].

The mechanisms of involvement of the Akt pathway in tumorigenesis are multifold. Activated Akt has wellestablished anti-apoptotic activities. These are carried via inhibition of release of cytochrome c from the mitochondria or by its regulatory effect on various downstream effectors, e.g. NF- $\mathrm{kB}, \mathrm{Bcl}-2$ family proteins, FOXO transcription factors and MDM2, which in turn stimulate tissue growth $[5,6]$. In addition, Akt activation mediates cell cycle progression via inhibition of glycogen synthase kinase 3beta, opposing the action of p21WAF1 and p27Kip1 and by phosphorylation of AKT/mTOR kinases [7]. The latter results in increased translation of cyclin D1, D3, and E transcripts and carries special significance with regard to anti-cancer therapeutics. mTOR inhibition by rapamycin derivative, everolimus, has been shown by Majumder et al. to reverse AKT-dependent prostate intraepithelial neoplasia [8].

The Akt signaling pathway also influences other facets of tumorigenesis. For example, Akt stimulates angiogenesis facilitating tumor growth [9]. This is due to the mediation of the effects of VEGF by the Flk1/VEGFR2-PI3K-AKT pathway [10]. Other hallmarks of malignancy such as tumor invasion and metastasis are also affected by Akt activation [11]. This is due to the increased secretion of matrix metalloproteinases and the induction of epithelial-mesenchymal transition [12]. Akt has also been shown to stimulate telomerase activity and replication [13]. 


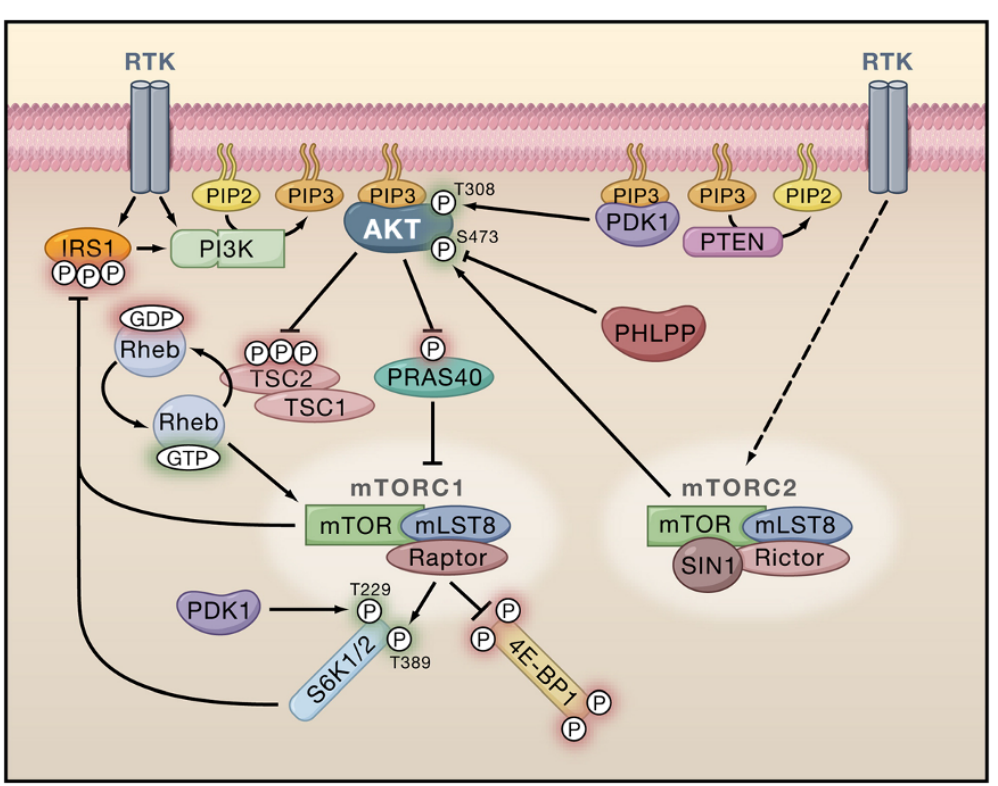

Figure 1 The PI3K/Akt/mTOR signaling pathway [3].

The spectrum of mutations leading to Akt activation is diverse and mostly affects the PI3K/Akt/mTOR pathway (Table 1) [14]. Amplication and overexpression of Akt2 was first shown to occur in ovarian cancers [15]. Since then, overexpression of Akt2 has been shown to occur in pancreatic cancers, hepatocellular carcinomas, colorectal cancers, stomach cancers and various forms of breast cancers [16-19]. On the other hand, amplification of Akt1 is relatively uncommon, and has been detected in only a few cases of gastric carcinoma and gliosarcoma $[20,21]$. Expression of Akt3 mRNA has also been found to be upregulated in estrogen receptor-negative breast carcinomas [22]. Furthermore, Akt has also been found as a culprit for tumor cell resistance to chemotherapy

Table 1 Common mutations in the PI3K/Akt/mTOR pathway [14]

\begin{tabular}{|c|c|c|}
\hline Targets & Genetic alteration & Cancer type \\
\hline \multirow[t]{2}{*}{$\begin{array}{l}\text { PIK3CA (phosphoinositide-3-kinase, } \\
\text { catalytic, a-polypeptide) }\end{array}$} & Mutations & $\begin{array}{l}\text { Breast, endometrial, colon, upper digestive tract, gastric, pancreas, ovarian, } \\
\text { liver, brain, oesophageal, lung, melanoma, urinary tract, prostate, thyroid }\end{array}$ \\
\hline & Amplifications & $\begin{array}{l}\text { Lung (squamous cell), lung (adenocarcinoma), lung (small cell), lung } \\
\text { (non-small cell), cervical, breast, head and neck, gastric, thyroid, } \\
\text { oesophageal, endometrial, ovarian, glioblastoma }\end{array}$ \\
\hline \multirow{2}{*}{$\begin{array}{l}\text { PIK3CB (phosphoinositide-3-kinase, } \\
\text { catalytic, } \beta \text {-polypeptide) }\end{array}$} & Amplifications & Ovarian, breast \\
\hline & Increase in activity and expression & Colon, bladder \\
\hline $\begin{array}{l}\text { PDPK1 (3-phosphoinositide } \\
\text { dependent protein kinase-1) }\end{array}$ & Amplifications and overexpression & Breast \\
\hline \multirow[t]{3}{*}{$\begin{array}{l}\text { AKT (v-akt murine thymoma } \\
\text { viral oncogene homologue) }\end{array}$} & $\begin{array}{l}\text { AKT homologue } 1 \text { mutation (E17K) } \\
\text { or amplifications }\end{array}$ & Breast, colon, ovarian, lung, gastric \\
\hline & AKT homologue 2 amplifications & Ovarian, pancreas, head and neck, breast \\
\hline & $\begin{array}{l}\text { AKT homologue } 3 \text { mutation (E17K) } \\
\text { or amplifications }\end{array}$ & Skin, glioblastoma \\
\hline $\begin{array}{l}\text { PIK3R1 (phosphoinositide-3-kinase, } \\
\text { regulatory subunit-1) }\end{array}$ & Mutations & Glioblastoma, ovarian, colon \\
\hline \multirow{2}{*}{$\begin{array}{l}\text { PTEN (phosphatase and } \\
\text { tensin homologue) }\end{array}$} & Loss of heterozygosity & Gastric, breast, melanoma, prostate, glioblastoma \\
\hline & Mutations & $\begin{array}{l}\text { Endometrial, brain, skin, prostate, colon, ovary, breast, haematopoietic and } \\
\text { lymphoid tissue, stomach, liver, kidney, vulva, urinary tract, thyroid, lung }\end{array}$ \\
\hline
\end{tabular}


while treating breast cancer, ovarian cancer and pancreatic cancer [16,23]. A mutation in the Akt1 gene is also known to cause the Proteus Syndrome [24]. Akt1, measured by immunohistochemistry techniques, has been shown to be a marker of response to radiation therapy in head and neck cancers [25].

A plethora of Akt inhibitors is under pre-clinical and clinical trials. Various drug trials have been initiated for Akt Inhibitors. However, miltefosine, is the only Akt inhibitor which has recently got approved by FDA albeit for use in treatment of leishmaniasis. Akt inhibitors can be divided into six major classes based on their mechanisms of action. The first class contains ATP competitive inhibitors of Akt. These include compounds such as CCT128930 and GDC-0068, which inhibit Akt2 and Akt1, respectively $[26,27]$. The latter has successfully entered Phase II trials. This category also includes the panAkt kinase inhibitors such as GSK2110183 (afuresertib), which has entered Phase II trials, GSK690693, which entered Phase I trials for refractory hematologic malignancies, but was withdrawn prior to enrolment, and AT7867, which is still in pre-clinical phase [28-30]. The second class contains lipid-based Akt inhibitors which act by preventing the generation of PIP3 by PI3K. This mechanism is utilized by phosphatidylinositol analogs such as Calbiochem Akt Inhibitors I, II and III (category no. 124005, 124008, 124009 respectively) or other PI3K inhibitors such as PX866 [31]. This category also includes compounds such as Perifosine that entered phase III trials for colorectal cancer and multiple myeloma, but failed in 2012 [32]. The third class contains a group of compounds called psuedosubstrate inhibitors. These include compounds such as AKTide-2 $\mathrm{T}$ and FOXO3 hybrid [33,34]. The fourth class consists of allosteric inhibitors of AKT kinase domain, and include compounds such as MK2206. The fifth class consists of antibodies and include entities such as GSTanti-Akt1-MTS. The last class comprises of compounds that interact with the PH domain of Akt, and include compounds such as Triciribine and PX-316. Apart from these, other molecules such as the Akt-1 Antisense Oligonucleotide RX-0201, have also yielded favorable results [35].

In short, the use of Akt inhibitors as monotherapy or in combination with other anticancer drugs could be useful for combating drug resistance and improving response. Thus, comprehensive understanding of Akt and its linked signaling pathways (PI3K, PKB, mTOR etc.) is necessary to lead to newer drug development and use [36].

\section{Competing interests}

The authors declare that that have no competing interests.

\section{Authors' contributions}

AS conceived the topic. JB was involved in drafting the initial manuscript. AS and AKN were involved in critically revising the manuscript, listed in decreasing order of their contributions. The authors have read and approved the manuscript. The authors did not receive any financial support/grant.

\section{Author details}

'Post Graduate Institute of Medical Sciences, Rohtak, Haryana, India. ${ }^{2}$ Dow Medical College, Dow University of Health Sciences, Karachi, Pakistan. ${ }^{3}$ Shifa College of Medicine, H-8/4, Islamabad, Pakistan. ${ }^{4}$ Pakistan Research Evolution Scientific Society, Baba-e-Urdu Road, Karachi 74200, Pakistan.

Received: 23 June 2013 Accepted: 18 November 2013 Published: 13 December 2013

\section{References}

1. Garofalo RS, Orena SJ, Rafidi K, Torchia AJ, Stock JL, Hildebrandt AL, Coskran T, Black SC, Brees DJ, Wicks JR, et al: Severe diabetes, age-dependent loss of adipose tissue, and mild growth deficiency in mice lacking Akt2/PKB beta. J Clin Invest 2003, 112(2):197-208.

2. Yang ZZ, Tschopp O, Baudry A, Dummler B, Hynx D, Hemmings BA: Physiological functions of protein kinase B/Akt. Biochem Soc Trans 2004, 32(Pt 2):350-354.

3. Manning BD, Cantley LC: AKT/PKB signaling: navigating downstream. Cell 2007, 129(7):1261-1274.

4. Pommery N, Henichart JP: Involvement of PI3K/Akt pathway in prostate cancer-potential strategies for developing targeted therapies. Mini Rev Med Chem 2005, 5(12):1125-1132.

5. Song G, Ouyang G, Bao S: The activation of Akt/PKB signaling pathway and cell survival. J Cell Mol Med 2005, 9(1):59-71.

6. Whang YE, Yuan XJ, Liu Y, Majumder S, Lewis TD: Regulation of sensitivity to TRAIL by the PTEN tumor suppressor. Vitam Horm 2004, 67:409-426.

7. Liang J, Slingerland JM: Multiple roles of the PI3K/PKB (Akt) pathway in cell cycle progression. Cell Cycle 2003, 4(2):339-345.

8. Majumder PK, Febbo PG, Bikoff R, Berger R, Xue Q, McMahon LM, Manola J, Brugarolas J, McDonnell TJ, Golub TR, et al: mTOR inhibition reverses Akt-dependent prostate intraepithelial neoplasia through regulation of apoptotic and HIF-1-dependent pathways. Nat Med 2004, 10(6):594-601.

9. Somanath PR, Razorenova OV, Chen J, Byzova TV: Akt1 in endothelial cell and angiogenesis. Cell Cycle 2006, 5(5):512-518.

10. Shiojima I, Walsh K: Role of Akt signaling in vascular homeostasis and angiogenesis. Circ Res 2002, 90(12):1243-1250.

11. Lefranc F, Brotchi J, Kiss R: Possible future issues in the treatment of glioblastomas: special emphasis on cell migration and the resistance of migrating glioblastoma cells to apoptosis. $J$ Clin Oncol 2005, 23(10):2411-2422

12. Thant AA, Nawa A, Kikkawa F, Ichigotani $Y$, Zhang $Y$, Sein $\Pi$, Amin AR, Hamaguchi M: Fibronectin activates matrix metalloproteinase-9 secretion via the MEK1-MAPK and the PI3K-Akt pathways in ovarian cancer cells. Clin Exp Metastasis 2000, 18(5):423-428.

13. Liu JP: Studies of the molecular mechanisms in the regulation of telomerase activity. FASEB J 1999, 13(15):2091-2104.

14. Hsieh AC, Truitt ML, Ruggero D: Oncogenic AKTivation of translation as a therapeutic target. Br J Cancer 2011, 105(3):329-336.

15. Cheng JQ, Godwin AK, Bellacosa A, Taguchi T, Franke TF, Hamilton TC, Tsichlis PN, Testa JR: AKT2, a putative oncogene encoding a member of a subfamily of protein-serine/threonine kinases, is amplified in human ovarian carcinomas. Proc Natl Acad Sci U S A 1992, 89(19):9267-9271.

16. Cheng JQ, Ruggeri B, Klein WM, Sonoda G, Altomare DA, Watson DK, Testa JR: Amplification of AKT2 in human pancreatic cells and inhibition of AKT2 expression and tumorigenicity by antisense RNA. Proc Natl Acad Sci USA 1996, 93(8):3636-3641.

17. Xu X, Sakon M, Nagano H, Hiraoka N, Yamamoto H, Hayashi N, Dono K, Nakamori S, Umeshita K, Ito Y, et al: Akt2 expression correlates with prognosis of human hepatocellular carcinoma. Oncol Rep 2004, 11(1):25-32.

18. Agarwal $\mathrm{E}$, Brattain MG, Chowdhury S: Cell survival and metastasis regulation by Akt signaling in colorectal cancer. Oncol Rep 2013, 25(8):1711-1719.

19. Soung YH, Lee JW, Nam SW, Lee JY, Yoo NJ, Lee SH: Mutational analysis of AKT1, AKT2 and AKT3 genes in common human carcinomas. Oncology 2006, 70(4):285-289.

20. Staal SP: Molecular cloning of the akt oncogene and its human homologues AKT1 and AKT2: amplification of AKT1 in a primary human gastric adenocarcinoma. Proc Natl Acad Sci U S A 1987, 84(14):5034-5037.

21. Knobbe CB, Reifenberger $G$ : Genetic alterations and aberrant expression of genes related to the phosphatidyl-inositol-3'-kinase/protein kinase B (Akt) signal transduction pathway in glioblastomas. Brain Pathol 2003, 13(4):507-518 
22. Nakatani K, Thompson DA, Barthel A, Sakaue H, Liu W, Weigel RJ, Roth RA: Up-regulation of Akt3 in estrogen receptor-deficient breast cancers and androgen-independent prostate cancer lines. J Biol Chem 1999, 274(31):21528-21532.

23. Bellacosa A, de Feo D, Godwin AK, Bell DW, Cheng JQ, Altomare DA, Wan M, Dubeau L, Scambia G, Masciullo V, et al: Molecular alterations of the AKT2 oncogene in ovarian and breast carcinomas. Int J Cancer 1995, 64(4):280-285.

24. Lindhurst MJ, Sapp JC, Teer JK, Johnston JJ, Finn EM, Peters K, Turner J, Cannons JL, Bick D, Blakemore L, et al: A mosaic activating mutation in AKT1 associated with the Proteus syndrome. N Engl J Med 2011, 365(7):611-619.

25. Gupta AK, McKenna WG, Weber CN, Feldman MD, Goldsmith JD, Mick R, Machtay M, Rosenthal DI, Bakanauskas VJ, Cerniglia GJ, et al: Local recurrence in head and neck cancer: relationship to radiation resistance and signal transduction. Clin Cancer Res 2002, 8(3):885-892.

26. Yap TA, Walton Ml, Hunter $L$, Valenti M, de Haven Brandon A, Eve PD, Ruddle R, Heaton SP, Henley A, Pickard L, et al: Preclinical pharmacology, antitumor activity, and development of pharmacodynamic markers for the novel, potent AKT inhibitor CCT128930. Mol Cancer Ther 2011, 10(2):360-371.

27. Blake JF, Xu R, Bencsik JR, Xiao D, Kallan NC, Schlachter S, Mitchell IS, Spencer KL, Banka AL, Wallace EM, et al: Discovery and preclinical pharmacology of a selective ATP-competitive Akt inhibitor (GDC-0068) for the treatment of human tumors. J Med Chem 2012, 55(18):8110-8127.

28. ClinicalTrials.gov $\mid$ An Open-Label Phase 2 Study of Ofatumumab (Arzerra) in Combination With Oral GSK2110183 in the Treatment of Relapsed and Refractory Chronic Lymphocytic Leukemia (CLL). [http:// clinicaltrials.gov/ct2/show/NCT01532700]

29. ClinicalTrials.gov | Study to Investigate AKT Inhibitor GSK690693 in Subjects With Relapsed or Refractory Hematologic Malignancies. [http:// clinicaltrials.gov/ct2/show/NCT00666081]

30. Grimshaw KM, Hunter LJ, Yap TA, Heaton SP, Walton MI, Woodhead SJ, Fazal L, Reule M, Davies TG, Seavers LC, et al: AT7867 is a potent and oral inhibitor of AKT and p70 S6 kinase that induces pharmacodynamic changes and inhibits human tumor xenograft growth. Mol Cancer Ther 2010, 9(5):1100-1110.

31. Hu Y, Qiao L, Wang S, Rong SB, Meuillet EJ, Berggren M, Gallegos A, Powis G, Kozikowski AP: 3-(Hydroxymethyl)-bearing phosphatidylinositol ether lipid analogues and carbonate surrogates block Pl3-K, Akt, and cancer cell growth. J Med Chem 2000, 43(16):3045-3051.

32. Kondapaka SB, Singh SS, Dasmahapatra GP, Sausville EA, Roy KK: Perifosine, a novel alkylphospholipid, inhibits protein kinase $B$ activation. Mol Cancer Ther 2003, 2(11):1093-1103.

33. Luo Y, Smith RA, Guan R, Liu X, Klinghofer V, Shen J, Hutchins C, Richardson P, Holzman T, Rosenberg SH, et al: Pseudosubstrate peptides inhibit Akt and induce cell growth inhibition. Biochemistry 2004, 43(5):1254-1263.

34. Barnett SF, Bilodeau MT, Lindsley CW: The Akt/PKB family of protein kinases: a review of small molecule inhibitors and progress towards target validation. Curr Top Med Chem 2005, 5(2):109-125.

35. National Cancer Institute, NIH. Drug Dictionary. [http://www.cancer.gov/ drugdictionary]

36. Pal SK, Reckamp K, Yu H, Figlin RA: Akt inhibitors in clinical development for the treatment of cancer. Expert Opin Investig Drugs 2010, 19(11):1355-1366

doi:10.1186/1750-9378-8-49

Cite this article as: Bhutani et al: Akt inhibitors: mechanism of action and implications for anticancer therapeutics. Infectious Agents and Cancer 2013 8:49.

\section{Submit your next manuscript to BioMed Central and take full advantage of:}

- Convenient online submission

- Thorough peer review

- No space constraints or color figure charges

- Immediate publication on acceptance

- Inclusion in PubMed, CAS, Scopus and Google Scholar

- Research which is freely available for redistribution

Submit your manuscript at www.biomedcentral.com/submit 